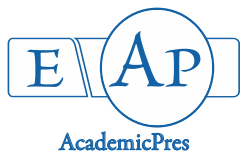

Shahrajabian MH et al. (2021)

Notulae Scientia Biologicae 13(1):10816

DOI: $10.15835 / \mathrm{nsb} 13110816$

Review Article

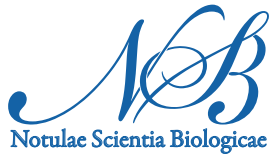

\title{
Spanish chamomile (Anacyclus pyrethrum) and pyrethrum (Tanacetum cineraiifolium): organic and natural pesticides and treasure of medicinal herbs
}

\author{
Mohamad H. SHAHRAJABIAN ${ }^{1 a *}$, Wenli SUN ${ }^{1 \mathrm{~b}}$, Qi CHENG ${ }^{1,2}$ \\ ${ }^{1}$ Chinese Academy of Agricultural Sciences, Biotechnology Research Institute, Beijing 100081, China; \\ hesamshahrajabian@gmail.com ("correspondingauthor); sunwenli@caas.cn; chengqi@caas.cn; \\ ${ }^{2}$ Hebei Agricultural University, College of Life Sciences, Baoding, Hebei, 071000, China; \\ ${ }^{a, b}$ These authors contributed equally to the work
}

\begin{abstract}
Pyrethrum ( Tanacetum cineraiifolium) which is a natural insecticide has many properties, but the most important are raid action, very low toxicity for mammalian, lack of insect immunity, broad of activity, lack of persistence and degraded quickly by UV in sunlight and very effective insect repellent. Organic farmers can use pyrethrins as an insecticide for fruit and vegetable crops. Easily degraded by oxygen, light and temperature, pyrethrum compounds are environmentally friendly and compatible with organic farming. A. pyrethrum roots contain anacyclin, pellitorine, hydrocarolin, inulin, traces of volatile oil and seasamin. The roots of $A$. pyrethrum are used in traditional medicine of different countries to treat epilepsy, rheumatism, cephalalgia, paralysis and hemiplegia. $\mathrm{N}$-alkylamids and ester pyrethrine are the main constituents of roots which have tremendous medicinal values. The plant is also a natural pesticide with considerable antimicrobial properties. It has also possessed antidepressant, anti-inflammatory, anticonvulsive, antimicrobial, local anaesthetic, oxidative DNA damage preventive, immunostimulatory, saliva-stimulating, male libido enhancing, antimutagenesis and insecticidal activities.
\end{abstract}

Keywords: Anacyclus pyrethrum; medical herb; natural pesticide; pyrethrum; Tanacetum cineraiifolium

\section{Introduction}

Herbal medicinal plants are commonly used for the cure and prevention of countless diseases because of low price and more effectiveness with low side effects (Sun et al., 2019a, b; Sun et al., 2021a, b, c). Medicinal plants play an important role in sustainable agriculture, food systems and it is also offering a holistic and meaningful approach to prevent diseases, and fight against insects and pests while making suitable usage of organic and herbal products (Shahrajabian et al., 2020a, b, c). Medicinal plants contain phytochemical and bioactive compounds such as phenols, saponin, flavonoids, alkaloids and etc (Shahrajabian et al., 2019a, b, c; Shahrajabian et al., 2021).

Received: 20 Sep 2020. Received in revised form: 01 Mar 2021. Accepted: 02 Mar 2021. Published online: 03 Mar 2021.

From Volume 13, Issue 1, 2021, Notulae Scientia Biologicae journal will use article numbers in place of the traditional method of continuous pagination through the volume. 
We gathered relevant and informative literature related to this research study from different sources. The goal of this review is survey on important traditional and modern pharmaceutical uses of Tanacetum cineraiifolium and Anacyclus pyrethrum.

\section{Tanacetum cineraiifolium and Anacyclus pyrethrum, Occurrence and Cultivation}

Botanical insecticides keep attracting more attention from environmental and small farmers worldwide as they are considered as a suitable alternative to synthetic insecticides (Pavela, 2016). Pyrethrum (Tanacetum cineraiifolium) is a perennial in the Asteraceae that has been widely used for pyrethrin production (Wandahwa and Ranst, 1996; Hay et al., 2008; Bhuiyan et al., 2015; Bhuiyan et al., 2018; Moslemi et al., 2018).The interest in sustainable agriculture has increased in recent years, and the demand for plant-derived pesticides which can be less toxic both to mammals and to the environment (Keskitalo et al., 1999; Kiriamiti et al., 2003; Pethybridge et al., 2004; Jansen et al., 2010). Insecticidal pyrethrins are extracted from the achenes within the flower heads (Grdisa et al., 2009), and represent the economically most important natural pesticide which are neurotoxins effective against a wide range of insect species, and broadly applied in private homes, gardens, stables and organic agriculture, because they have environmentally friendly properties. About 200 years ago, it was discovered in Central Asia. During the Napoleonic wars (1804-1815) this insect was used to control flea and body lice infestations by French soldiers. The white Chrysanthemum flower, pyrethrum, is a mentioned in early Chinese history and it is believed to have passed into Europe along the silk routes. The first record of the pyrethrum was 2000 years ago at the time of China's Chou Dynasty, then the flowers have been traded along ancient Silk Road and was grown in the Dalmatian region. But, the species of plant was unknown, so, for convenience the history of pyrethrum usually starts with the mention in 1847 of the identified species Chrysanthemum cinerariaefolium found in Dalmatia which is part of Croatia. From 1885, bales of dried flowers were exported to the USA and during 1913, 500 tonnes were shipped. Although the earliest mention of the Chrysanthemum flowers from which it originates comes from early Chinese history, where it is believed that the flower passed into Europe along the silk roads. The term pyrethrum refers to the dried and powdered flower heads of a white-flowered, daisy-like plant belonging to the Chrysanthemum genus. Pyrethrum's insecticidal properties were recognized in the middle of the 19th century, when an American named Jumticoff discovered that many Caucuses tribes used it for the control of the body lice. The earliest cultivation of pyrethrum, also called Persian pyrethrum or Persian powders, was in the region of the Caucuses extending into Northern Persia. The first Persian powders that were processed and commercialized in Europe in the 1820s were most likely prepared from a mixture of $C$. roseum and $C$. corneum. The first major commercial planting was done in Yugoslavia prior to 1914, thereafter Japan was the main producer until 1939 when Kenya and other East African countries took over after the second world war. Several attempts have been made to grow pyrethrum as a commercial crop in different parts of Australia between 1890 to 1964 (Bhat and Menary, 1984). Pyrethrum was first introduced into Tasmania and a crop improvement program begun in 1978. The commercial production of the crop started with selected clones from the program in 1984 (Bhat and Menary, 1984), and the crop is well stablished and commercially viable in Tasmania. Tasmania is one the largest pyrethrum producer. On a dry weight basis, a pyrethrum inflorescence contains the majority of the plants' active compounds, reported in the range 1-2\% pyrethrins (Fulton, 1998; Sastry et al., 2001). Pyrethrum is highly effective against many species of insects but its toxicity to people and warm-blooded animals is low because of its fast biotransformation (Duchon et al., 2009; Sharafzadeh, 2011). Pyrethrum could be used by municipal utilities or in organic, integrated or conventional crop cultivation because of its natural origin and high biocide effect; pyrethrum has been used mainly for protection of cereal products, vegetables and animals, and it could also be used to protect human habitats and animals against insects. There are some possible uses: the first is spraying the fine dry pulp of flowers and the other spraying their extract. A third form is incense sticks to protect against mosquitoes causing malaria (Toth et al., 2012). Pyrethrum is a white flower headed, 
tufted perennial herbaceous plant possessing deeply lobed leaves, with numerous and fibrous shallow root system $(30 \mathrm{~cm})$. The plant has numerous fairly rigid stems that grow up to 50 to $80 \mathrm{~cm}$ in height with bluegreen deeply divided leaves that are covered on both sides by a dense woolly material. Pyrethrum requires rich soils in phosphorous, calcium and magnesium with a minimum soil $\mathrm{pH}$ of 5.6. The appropriate situation is fertile and well drained soils with reasonably possess good texture and structure. This crop is spring sown, with its first harvest occurring approximately 15 months after establishment and up to three subsequent annual harvests thereafter (Vaghefi et al., 2016). Ray blight is one of the most important disease of pyrethrum which produces typical nercrotic symptoms on leaf margins, shoots and developing buds in spring (Pethybridge et al., 2008; Vaghefi et al., 2016). Pethybridge and Wilson (1998) reported that the most serious fungal foliar disease of pyrethrum in Tasmania is ray blight caused by Phoma ligulicola, the anamorph of Didymella ligulicola. The root of Anacyclus pyrethrum is used in traditional Iranian medicine (TIM), which has studied for anticonvulsant effects (Abdollahi and Shojaii, 2013). Ebn-e-Sina, prescribed it in erectile dysfunctions (ED) treatment (Khaleghi Ghadiri and Gorji, 2004). Ahmed and Venkataraman (1999) indicated that this crop constitutes a major part of poly-herbal ayurvedic medicine (PAM), which used for treating male sexual dysfunction in the Indian subcontinent. Boonen et al. (2011) reported that the roots of Anacyclus pyrethrum are frequently used in traditional medicine such as aphrodisiac. Hanane et al. (2014) confirmed that the phytochemical screening of Anacylcus pyrethrum has led to the identification of various secondary metabolites such as alkaloids, reducing compounds, tannins, flavonoids and coumarins. Scientific classification of Anacyclus pyrethrum is shown in Table 1.

Table 1. Scientific classification of Anacyclus pyrethrum

\begin{tabular}{|c|c|}
\hline Kingdom & Plantae \\
\hline Division & Spermatophyta \\
\hline Sub-division & Angiosperms \\
\hline Class & Dicotyledons \\
\hline Sub-class & Metachlamydae \\
\hline Order & Companulatae \\
\hline Family & Compositaeor Asteraceae \\
\hline Genus & Anacyclus \\
\hline Species & Pyrethrym \\
\hline
\end{tabular}

Biochemical constituents of $A$. pyrethrum consist of chlorophyll a $(0.240 \mathrm{mg} / \mathrm{g})$, chlorophyll b $(0.820$ $\mathrm{mg} / \mathrm{g})$, total chlorophyll $(1.060 \mathrm{mg} / \mathrm{g})$, amino acid $(160.0 \mathrm{mg} / \mathrm{g})$, protein $(3.140 \mathrm{mg} / \mathrm{g})$, carbohydrate $(1.726$ $\mathrm{mg} / \mathrm{g}$ ), and phenol $(0.788 \mathrm{mg} / \mathrm{g})$ (Subrasi and Ahmed John, 2016). The root extracts contain steroids, triterpenes, reducing sugars, sugars, alkaloids, flavonoids, saponins, tannins, anthraquinones, and amino acids; and phytochemical compounds in their leaves are steroids, triterpenes, sugars, alkaloids, flavonoids, saponins, tannins, anthraquinones and amino acids (Subrashi and Ahmed John, 2016; Usmani et al., 2016).

\section{Treasure of medicinal herbs with tremendous benefits}

Chesang et al. (2017) concluded that increased proportion of unstabilized pyrethrins in combination with diatomaceous earth offer grain protection comparable to the commercial chemical grain protectants. Pyrethrins can be separated into two groups of three ester compounds: pyrethrin I and II. The pyrethrin I fraction contains chrysanthemic acid products, including pyrethrin I, cinerin I, and jasmolin I. The pyrethrin II fraction is derived from pyrethric acid made up of pyrethrin II, cinerin II, and jasmolin II (Greening, 1983; Casida, 1990; Kimani and Sum, 1999; Elliott, 1995; Atkinson et al., 2004). Pyrethrins also have the advantage over other synthetic insecticides of being rapidly broken down upon exposure to light and air, are metabolized quickly, and can be used in the production of organic farm products, and they generally considered to be nonpolluting (Casida, 1990; Elliott, 1995).The plant Anacyclus pyrethrum consists of several $N$-alkylamides with 
pellitorine as main constituents, and its extracts are already commercially available with functional cosmeceutical claims (Veryser et al., 2014). Its root is widely used for treating various diseases in traditional Uygur medicine, particularly in the treatment of vitiligo (Ji et al., 2019). Rachida et al. (2014) reported that $A$. pyrethrum roots widely used in Moroccan traditional medicine in treatment of teeth disease and in treatment of memory disorders, besides, a mixture of roots and milk added by honey is proposed as aphrodisiac, against the feminine infertility. The most important active constituents of pyrethrins are pyrethrin $\mathrm{I}\left(\mathrm{C}_{21} \mathrm{H}_{28} \mathrm{O}_{3}\right)$, cinerin I $\left(\mathrm{C}_{20} \mathrm{H}_{28} \mathrm{O}_{3}\right)$, jasmolin I $\left(\mathrm{C}_{21} \mathrm{H}_{30} \mathrm{O}_{3}\right)$, pyrethrin II $\left(\mathrm{C}_{22} \mathrm{H}_{28} \mathrm{O}_{5}\right)$, cinerin $\mathrm{II}\left(\mathrm{C}_{21} \mathrm{H}_{28} \mathrm{O}_{5}\right)$ and jasmolin II $\left(\mathrm{C}_{22} \mathrm{H}_{30} \mathrm{O}_{5}\right)$ (Parleviet and Brewer, 1971). Roncevic et al. (2014) the roots of pyrethrum plants were characterized by a combination of loadings of iron, aluminium, nickel, chromium, strontium, and barium, while the stems, leaves, and flowers showed more contributions from sodium, potassium, calcium, magnesium, phosphorus, sulphur, manganese and copper. They have also observed that microelements such as copper, aluminium, and iron were more readily transferred into natural insecticide extracts. Rehman et al. (2014) stated that pyrethroids are broadly classified into first and second generation pyrethroids. The first generation (Type 10 pyrethroids are less toxic to mammals than the second generation (Type II) pyrethroids. Sujith et al. (2012) concluded that ethanolic extract of $A$. pyrethrum has been demonstrated to improve cognitive processes by enhancing memory in different experimental paradigms. They have suggested that ethanolic extract of $A$. pyrethrum increased brain cholinesterase level and hence it possess memory enhancing activity in scopolamine induced amnesia model by enhancing central cholinergic neurotransmission. Jalayer Naderi et al. (2012) mentioned biological activities of $A$. pyrethrum such as antibacterial, immune-stimulating and antioxidant, antidepressant. The most important pharmaceutical benefits of Anacyclus pyrethrum are presented in Table 2.

Table 2. Pharmaceutical benefits of Anacyclus pyrethrum

\begin{tabular}{|c|c|c|}
\hline Benefits & Mechanism and impacts & Reference \\
\hline $\begin{array}{l}\text { Oxidative stress, } \\
\text { neuroprotective } \\
\text { effects and cognitive } \\
\text { impairment }\end{array}$ & $\begin{array}{l}\text { a. The hydroalcoholic extract of } A \text {. pyrethrum (HEAP) root } \\
\text { significantly prevented seizure induced oxidative stress and cognitive } \\
\text { impairment in a dose-dependent manner. } \\
\text { b. HEAP also normalized the decrease in cholinesterase activity caused } \\
\text { by seizures. } \\
\text { c. The ethanolic extract of } A \text {. pyrethrum increased brain cholinesterase } \\
\text { level, so it possesses memory enhancing activity in scopolamine induced } \\
\text { amnesia model by increasing central cholinergic neurotransmission. } \\
\text { d. A. pyrethrum extracts attenuated the neuronal activation caused by } \\
\text { kainic acid injection in hippocampus; its extracts exhibited } \\
\text { neuroprotective following kainic acid injection in hippocampus. }\end{array}$ & $\begin{array}{c}\text { Pahuja et al. (2012) } \\
\text { Sujith et al. (2012) } \\
\text { Manouze et al. } \\
\text { (2019) }\end{array}$ \\
\hline Natural pesticide & $\begin{array}{l}\text { a. The most outstanding properties of pyrethrum are rapid action of } \\
\text { this insecticide, low mammalian toxicity, broad spectrum of activity, } \\
\text { lack of insect immunity, lack of persistence and very effective insect } \\
\text { repellent. } \\
\text { b. The pyrethrum maybe a potential candidate for the impregnation of } \\
\text { mosquito nets and textiles in areas where resistance to pyrethroids has } \\
\text { become problematic. }\end{array}$ & $\begin{array}{l}\text { Greening (1983) } \\
\text { Kimani and Sum } \\
\qquad(1999) \\
\text { Atkinson et al. } \\
\quad(2004) \\
\text { Duchon et al. } \\
\quad(2009)\end{array}$ \\
\hline $\begin{array}{l}\text { Immunostimulant } \\
\text { activity }\end{array}$ & $\begin{array}{l}\text { a. The fractions from } A \text {. pyrethrum showed a marked stimulating } \\
\text { impact on the reticuloendothelial and increased the number of } \\
\text { peritoneal exudates cells, and spleen cells of mice. }\end{array}$ & $\begin{array}{l}\text { Bendjeddou et al. } \\
\qquad(2003)\end{array}$ \\
\hline $\begin{array}{c}\text { Anticonvulsant and } \\
\text { neuro- } \\
\text { pharmacological } \\
\text { activity }\end{array}$ & & Zaidi et al. (2009) \\
\hline $\begin{array}{l}\text { Lowering Blood } \\
\text { sugar }\end{array}$ & $\begin{array}{l}\text { a. The aqueous root extract of Anacyclus pyrethrum significantly } \\
\text { reduced elevated blood glucose level in Alloxan diabetic rats without } \\
\text { showing any hypoglycaemic effect in normal rats. }\end{array}$ & Tyagi et al. (2011) \\
\hline
\end{tabular}




\begin{tabular}{|c|c|c|}
\hline $\begin{array}{l}\text { Immunomodulatory } \\
\text { activity }\end{array}$ & $\begin{array}{l}\text { A. pyrethrum can be considered as an adaptogen and } \\
\text { immunomodulator in the Ayurvedic system of medicine. }\end{array}$ & $\begin{array}{l}\text { Sharma et al. } \\
\text { (2010a) }\end{array}$ \\
\hline Anti-cancer activity & $\begin{array}{l}\text { a. The } A \text {. pyrethrum extract significantly inhibited the cell growth, and } \\
\text { it can successfully induce apoptosis in cancer cell line (HCT) cells; } \\
\text { therefore, it could be used as a novel therapeutic candidate for } \\
\text { colorectal cancer treatment. }\end{array}$ & $\begin{array}{l}\text { Mohammadi et al. } \\
\qquad \text { (2017) }\end{array}$ \\
\hline $\begin{array}{l}\text { Anti-inflammatory } \\
\text { activity }\end{array}$ & $\begin{array}{l}\text { a. The methanol extracts of roots are non-toxic substance, and can be } \\
\text { used in the treatment of pain and inflammatory disorders in humans. }\end{array}$ & $\begin{array}{l}\text { Rimbau et al. } \\
\quad(1996) \\
\text { Manouze et al. } \\
\quad(2017)\end{array}$ \\
\hline Antioxidant activity & $\begin{array}{l}\text { a. A. pyrethrum is a procumbent herb of immense medical value, largely } \\
\text { due to the presence of an array of therapeutically active alkaloids such as } \\
\text { pellitorine with antioxidant activities. }\end{array}$ & Singh et al. (2020) \\
\hline $\begin{array}{l}\text { Antimicrobial } \\
\text { activity }\end{array}$ & $\begin{array}{l}\text { a. Essential oils from the aerial parts of Anacyclus pyrethrum showed } \\
\text { activity against Candida albicans and Staphylococcusaureus bacteria } \\
\qquad \text { strains. } \\
\text { b. A. pyrethrum has antimicrobial activity against the tested microbial } \\
\text { species except E. faecalis and } S \text {. typhimurium. }\end{array}$ & $\begin{array}{l}\text { Selles et al. }(2013) \\
\text { Canli et al. }(2017)\end{array}$ \\
\hline $\begin{array}{l}\text { Improve sexual } \\
\text { parameters }\end{array}$ & $\begin{array}{l}\text { a. It may improve sexual parameters, and it can also prolong effect and } \\
\text { capacitate the treated rats for improved sexual potential. }\end{array}$ & $\begin{array}{l}\text { Sharma et al. } \\
\qquad(2010 \mathrm{~b}) \\
\text { Haghmorad et al. } \\
\quad(2019)\end{array}$ \\
\hline
\end{tabular}

\section{Conclusions}

Pyrethrum ( Tanacetum cinerariifolium) is a small perennial plant cultivated for extraction of pyrethrins from dried flower achenes. Pyrethrum flowers are used for the extraction of an important insecticide, the pyrethrins, which is non-toxic to humans are other warm-blooded animals. Pyrethrins are the active ingredients derived from the natural insecticide pyrethrum, and pyrethroids are synthetic or manufactured versions of pyrethrins. The active constituents of pyrethrins are, Pyrethrin I, Cinerin I, Jasmolin I, Pyrethrin II, Cinerin II and Jasmolin II. The combined usage of pyrethrin I and II have significant influence for pest control. Because, the human population is exposed to chemical pesticides which can lead to long term health hazards, the final goal of farmers should be at reducing consumption unnecessary pesticides and replacing chemical products with alternative organic and natural products to protect agricultural crops against insects. Organic farmers can use pyrethrins as an insecticide for fruit and vegetable crops. Pyrethrum can control pests in a difficult battle in a natural way. The roots of the plant Anacyclus pyrethrum DC are reported to have good medicinal value in traditional and modern system of medicine. The plant mainly contains alkaloids, tannins, triterpenes, flavonoids, sterols, some trace metals and phenols. $N$-alkylamids and ester pyrethrine are the main constituents of roots which have tremendous medicinal values. Anacyclus pyrethrum has various activity such as antibacterial, anti-fungal, anti-diabetic, anti-oxidant, anti-convulsant, anti-depressant, anxiolytic, inhibit release of acetylcholinesterase enzyme, aphrodisiac, anabolic, reproductive, immunological active polysaccharides and memory enhancing activity. This herb is useful for various diseases, but the most important ones are diabetes, anabolic, Alzheimer and aphrodisiac. Herbal remedies and other nutraceuticals are increasingly and extensively used by a substantial part of the population. Treatment with natural herbal medicines and organic insecticide and non-synthetic drugs are recommended. 


\section{Authors' Contributions}

All authors contributed equally to this research, such as data curation, formal analysis, funding acquisition, investigation, methodology, project administration, resources, software, supervision, validation, visualisation, writing review and editing. All authors read and approved the final manuscript.

\section{Acknowledgements}

This research received no specific grant from any funding agency in the public, commercial, or not-forprofit sectors.

\section{Conflict of Interests}

The authors declare that there are no conflicts of interest related to this article.

\section{References}

Abdollahi Fard M, Shojaii A (2013). Efficacy of Iranian traditional medicine in the treatment of epilepsy. BioMed Research International 692751:1-8. https://doi.org/10.1155/2013/692751

Ahmed KA, Venkataraman BV (1999). Assessment of a polyherbal ayuvedic medicine for sexual activity in rats. Indian Drugs 36:576-582.

Atkinson BL, Blackman AJ, Faber H (2004). The degradation of the natural pyrethrins in crop storage. Journal of Agricultural and Food Chemistry 52(2):280-287. https://doi.org/10.1021/jf0304425

Bendjeddou D, Lalaoui K, Satta D (2003). Immuno-stimulating activity of the hot water-soluble polysaccharide extracts of Anacyclus pyrethrum, Alpiniagalanga and Citrullus colocynthis. Journal of Ethnopharmacology 88(2-3):155160. https://doi.org/10.1016/s0378-8741(03)00226-5

Bhat BK, Menary RC (1984). Pyrethrum production in Australia: Its past and present potential. Journal of the Australian Institute of Agricultural Sciences 52:189-192. https://doi.org/10.2135/cropsci1984.0011183x002400030047x

Bhuiyan MAHB, Groom T, Nicolas ME, Taylor PWJ (2015). Histopathology of S. tanaceti infection in pyrethrum leaf lamina. Australian Plant Pathology 44:629-636. https://doi.org/10.1007/s13313-015-0377-0

Bhuiyan MAHB, Groom T, Nicolas ME, Taylor PWJ (2018). TaqMan PCR assay for detection and quantification of Stagonosporopsis tanaceti in pyrethrum seed and seedlings. European Journal of Plant Pathology 150:1041-1048. https://doi.org/10.1007/s10658-017-1343-1

Boonen J, Sharma V, Dixit V, Spiegeleer BD (2011). New N-alkylamides from Anacyclus pyrethrum. Planta Medica 7794. https://doi.org/10.1055/s-0031-1282578

Canli K, Yetgin A, Akata I, Altuner EM (2017). Antimicrobial activity and chemical composition screening of anacyclus pyrethrum root. Indian Journal of Pharmaceutical Education and Research 51(3):s244-s248. https://doi.org/10.5530/ijper.51.3s.22

Casida JE (1990). Pesticides and alternatives: innovative chemical and biological approaches to pest control. Elsevier Science Publishers, New York. https://doi.org/10.1016/0048-3575(91)90086-2

Chesang PK, Simiyu GM, Were P (2017). Assessment of efficacy of unstabilized pyrethrins and diatomaceous earth admisture on sitophilus zeamais in maize grains. International Journal of Entomology Research 2(1):51-54. https://doi.org/10.1603/ice.2016.105894

Duchon S, Bonnet J, Marcombe S, Zaim M, Corbel V (2009). Pyrethrum: A mixture of natural pyrethrins has potential for malaria vector control. Journal of Medical Entomology 46(3):516-522. https://doi.org/10.1603/033.046.0316

Elliott M (1995). Chemicals in insect control. In: Casida JE and Quistad GB (Eds). Pyrethrum Flowers: Chemistry, Toxicology and Uses. Oxford University Press, New York pp 3-31. https://doi.org/10.2307/2807884 
Fulton D (1998). Agronomic and seed quality studies in pyrethrum, ( Tanacetum cinerariaefolium). Sch. Bio. PhD thesis, School of Agricultural Sciences, University of Tasmania, Hobart.

Haghmorad D, Mahmoudi MB, Haghighi P, Alidadiani P, Shahvazian E, Tavasolian P, ... Mahmoudi M (2019). Improvement of fertility parameters with Tribulus Terrestris and Anacyclus pyrethrum treatment in male rats. International Brazilian Journal of Urology 45(5):1043-1054. https://doi.org/10.1590/s16775538.ibju.2018.0843

Hanane E, Aminata S, Fatima E, Amar B, Mohamed AE, Touriya Z (2014). Phytochemical study of Anacyclus pyrethrum (L.) of Middle Atlas (Morocco), and in vitro study of antibacterial activity of pyrethrum. Advances in Natural and Applied Sciences 8:131-140.

Hay FS, Stirling GR, Pethybridge SJ, Chung B (2008). A survey of nematodes associated with pyrethrum in Tasmania, Australia, and the susceptibility of pyrethrum cultivars to root-lesion nematode. Australian Plant Pathology 38:15. https://doi.org/10.1071/ap08068

Grdisa M, Carovic-Stanko K, Kolak I, Satovic Z (2009). Morphological and biochemical diversity of Dalmatian pyrethrum (Tanacetum cineraiifolium (Trevir.) Sch. Bip.). Agriculturae Conspectus Scientificus 74:73-80.

Greening HG (1983). An investigation of protectant treatments for farm-stored grain in New South Wales. Pyrethrum Post 15(3):78-84.

Jalayer Naderi N, Niakan M, Khodadadi E (2012). Determination of antibacterial activity of Anacyclus pyrethrum extract against some of the oral bacteria: an in vitro study. Journal of Dental, Shiraz University of Medical Sciences 13(2):59-63.

Jansen J-P, Defrance T, Warnier AM (2010). Effects of organic-farming-compatible insecticides on four aphid natural enemy species. Pest Management Science 66:650-656. https://doi.org/10.1002/ps.1924

Ji R, Quan Q, Guo X, Zhang J, Song Y, Zhu M, ... Liu Y (2019). Simultaneous determination of five N-alkylamides in the root of Anacyclus pyrethrum by HPLC and profiling of components in its methanolic root extract by UPLC/QTOF-MS. Revista Brasileira de Farmacognosia 29(2):152-161. https://doi.org/10.1016/j.bjp.2018.12.011

Keskitalo M, Angers P, Earle E, Pehu E (1999). Chemical and genetic characterization of calli derived from somatic hybridication between tansy (Tanacetum vulgare L.) and pyrethrum (Tanacetum cinerariifolium (Trevir.) Schultz-Bip.). Theoretical and Applied Genetics 98:1335-1343. https://doi.org/10.1007/s001220051200

Khaleghi Ghadiri M, Gorji A (2004). Natural remedies for impotence in medieval Persia. International Journal of Impotence Research 16:80-83. https://doi.org/10.1038/sj.ijir.3901153

Kimani SM, Sum KS (1999). Bio efficacy of essential oils extracted from pyrethrum vegetables waxy resins and green oils against stored product insect pests, Tribolium castaneum and Sitophilus oryzae. Pyrethrum Post 20(3):91-99.

Kiriamiti HK, Camy S, Gourdon C, Condoret JS (2003). Pyrethrin extraction from pyrethrum flowers using carbon dioxide. Journal of Supercritical Fluids 26:193-200. https://doi.org/10.1016/s0896-8446(02)00165-1

Manouze H, Bouchata O, Chemseddoha Gadhi A, Bennis M, Sokar Z, Ba-Mhamed S (2017). Anti-inflammatory, antinociceptive and antioxidant activities of methanol and aqueous extracts of Anacyclus pyrethrum roots. Frontiers in Pharmacology 8:598. https://doi.org/10.3389/fphar.2017.00598

Manouze H, Bouchatta O, Bennis M, Sokar Z, Ba-M'hamed S (2019). Anticonvulsive and neuroprotective effects of aqueous and methanolic extracts of Anacyclus pyrethrum root in kainic acid-induced-status epilepticus in mice. Epilepsy Research 158:106225. https://doi.org/10.1016/j.eplepsyres.2019.106225

Mohammadi A, Mansoori B, Baradaran PC, Baradaran SC, Baradaran B (2017). Anacyclus pyrethrum extract exerts anticancer activities on the human colorectal cancer cell line (HCT) by targeting apoptosis, metastasis and cell cycle arrest. Journal of Gastrointestinal Cancer 48(4):333-340. https://doi.org/10.1007/s12029-016-9884-7

Moslemi A, Ades PK, Crous PW, Groom T, Scott JB, Nicolas ME, Taylor PWJ (2018). Paraphoma chlamydocopiosa sp. nov. and Paraphoma pye sp. nov., two new species associated with leaf and crown infection of pyrethrum. Plant Pathology 67:124-135. https://doi.org/10.1111/ppa.12719

Pahuja M, Mehla J, Reeta KH, Joshi S, Gupta YK (2012). Root extract of Anacyclus pyrethrum ameliorates seizures, seizure-induced oxidative stress and cognitive impairment in experimental animals. Epilepsy Research 98(23):157-165. https://doi.org/10.1016/j.eplepsyres.2011.09.006

Parleviet JE, Brewer JG (1971). Suggestion and recommendation for the agronomic sector of the pyrethrum industry. Ministry of Agriculture, Kenya, Molo.

Pavela R (2016). History, presence and perspective of using plant extracts as commercial botanical insecticides and farm products for protection against insects- a Review. Plant Protect Science 52(4):229-241. https://doi.org/10.17221/31/2016-pps 
Pethybridge SJ, Wilson CR (1998). Confirmation of ray blight disease in pyrethrum in Australia. Australian Plant Pathology 27:45-48. https://doi.org/10.1071/ap98004

Pethybridge SJ, Hay FS, Wilson CR (2004). Pathogenicity of fungi commonly isolated from foliar disease in Tasmanian pyrethrum crops. Australian Plant Pathology 33:441-444. https://doi.org/10.1071/ap04027

Pethybridge SJ, Hay FS, Esker PD, Gent DH, Wilson CR, Groom T, Nutter FW Jr (2008). Diseases of pyrethrum in Tasmania: challenges and prospects for management. Plant Disease 92(9):1260-1272. https://doi.org/10.1094/pdis-92-9-1260

Rachida A, Maryam M, Hanane K, Hind F, Loubna F, Fatiha C, ... Abderrahman C (2014). Scopolamine-induced impairment in conditioning and exploratory behaviours is enhanced by Anacyclus Pyrethrum in rats. International Journal of Engineering Research and Technology 3(4):1757-1761.

Rehman H, Aziz AT, Saggu S, Abbas ZK, Mohan A, Ansari AA (2014). Systematic review on pyrethroid toxicity with special reference to deltamethrin. Journal of Entomology and Zoology Studies 2(6):60-70.

Rimbau V, Risco E, Canigueral S, Iglesias J (1996). Antiinflammatory activity of some extracts from plants used in the traditional medicine of North-African countries. Phytotherapy Research 10(5):421-423. https://doi.org/10.1002/(sici)1099-1573(199608)10:5

Roncevic S, Svedruzic LP, Nemet I (2014). Elemental composition and chemometric characterization of pyrethrum plant materials and insecticidal flower extracts. Analytical Letters 47:627-640. https://doi.org/10.1080/00032719.2013.845898

Sastry KP, Dinesh K, Radhakrishnan K, Saleem SM, Sushil K (2001). Flowering characteristics of pyrethrum Chrysanthemum cinerariaefolium clones selected for high capitulum yield. Journal of Medicinal and Aromatic Plant Sciences 22/23:344-347.

Selles C, Dib MEA, Djabou N, Beddou F, Muselli A, Tabti B, ... Hammouti B (2013). Antimicrobial activity and evolution of the composition of essential oil from Algerian Anacyclus pyrethrum L. through the vegetative cycle. Natural Product Research 27(23):2231-2234. https://doi.org/10.1080/14786419.2013.811409

Shahrajabian MH, SunW, Zandi P, Cheng Q(2019a). A review of chrysanthemum, the eastern queen in traditional Chinese medicine with healing power in modern pharmaceutical sciences. Applied Ecology and Environmental Research 17(6):13355-13369. https://doi.org/10.15666/acer/1706_1335513369

ShahrajabianMH, Sun W, Cheng Q (2019b). A review of astragalus species as foodstuffs, dietary supplements, a traditional Chinese medicine and a part of modern pharmaceutical science. Applied Ecology and Environmental Research 17(6):13371-13382. https://doi.org/10.15666/aeer/1706_1337113382

ShahrajabianMH, Sun W, Cheng Q (2019c). Clinical aspects and health benefits of ginger (Zingiber officinale) in both traditional Chinese medicine and modern industry. Acta Agriculturae Scandinavica, Section B-Soil \& Plant Science. https://doi.org/10.1080/09064710.2019.1606930

Shahrajabian MH, Sun W, Cheng Q (2020a). Traditional herbal medicine for the prevention and treatment of cold and flu in the Autumn of 2020, overlapped with COVID-19. Natural Product Communications 15(8):1-10. https://doi.org/10.1177/19345778x20951431

Shahrajabian MH, Sun W, Cheng Q (2020b). Product of natural evolution (SARS, MERS and SARS-CoV-2); deadly disease, from SARS to SARS-CoV-2. Human Vaccines and Immunotherapeutics. https://doi.org/10.1080/21645515.2020.1797369

Shahrajabian MH, Sun W, Shen H, Cheng Q (2020c). Chinese herbal medicine for SARS and SARS-CoV-2 treatment and prevention, encouraging using herbal medicine for COVID-19 outbreak. Acta Agriculturae Scandinavica, Section B- Soil and Plant Science. https://doi.org/10.1080/09064710.2020.1763448

Shahrajabian MH, Sun W, Cheng Q (2021). Improving health benefits with considering traditional and modern health benefits of Peganum harmala. Clinical Phytoscience 7(1):1-9. https://doi.org/10.1186/s40816-021-00255-7

Sharafzadeh S (2011). Pyrethrum, coltsfoot and dandelion: important medicinal plants from Asteraceae family. Australian Journal of Basic and Applied Sciences 5(12):1787-1791.

Sharma V, Thakur M, Chauhan NS, Dixit VK (2010a). Immunomodulatory activity of petroleum ether extract of Anacyclus pyrethrum. Pharmaceutical Biology 48(11):1247-1254. https://doi.org/10.3109/13880201003730642

Sharma V, Thakur M, Chauhan NS, Dixit VK (2010b). Effects of petroleum ether extract of Anacyclus pyrethrum DC. On sexual behaviour in male rats. Journal of Chinese Integrative Medicine 8(8):767-773.

Sing DK, Babbar SB, Mir BA (2020). Antioxidant activity of explants specific calli of Anacyclus pyrethrum. Journal of Biologically Active Products from Nature 10(3):183-191. https://doi.org/10.1080/22311866.2020.1789504 
Subasri G, Ahmed John S (2016). Screening of phytochemical compounds, trace metals and antimicrobial activity of Anacyclus pyrethrum. International Journal of Advances in Scientific Research 2(1):32-37. https://doi.org/10.7439/ijasr.v2i1.2891

Sun W, Shahrajabian MH, Cheng Q (2019a). Anise (Pimpinella anisum L.), a dominant spice and traditional medicinal herb for both food and medicinal purposes. Cogent Biology 5(1673688):1-25. https://doi.org/10.1080/23312025.2019.1673688

Sun W, Shahrajabian MH, Cheng Q (2019b). The insight and survey on medicinal properties and nutritive components of shallot. Journal of Medicinal Plant Research 13(18):452-457. https://doi.org/10.5897/jmpr2019.6836

Sun W, Shahrajabian MH, Cheng Q (2021a). Health benefits of wolfberry (Gou Qi Zi) on the basis of ancient herbalism and Western modern medicine. Avicenna Journal of Phytomedicine 11(2):109-119. https://doi.org/10.1186/s40816-021-00255-7

Sun W, Shahrajabian MH, Cheng Q (2021b). Barberry (Berberis vulgaris), a medicinal fruit and food with traditional and modern pharmaceutical uses. Israel Journal of Plant Sciences 68(1-2):1-11. https://doi.org/10.1163/22238980-bja10019

Sun W, Shahrajabian MH, Cheng Q (2021c). Fenugreek cultivation with emphasis on historical aspects and its uses in traditional medicine and modern pharmaceutical science. Mini Reviews in Medicinal Chemistry 21(6):724-730. https://doi.org/10.2174/1389557520666201127104907

Sujith K, Darwin CR, Sathish, Suba V (2012). Memory-enhancing activity of Anacyclus pyrethrum in albino Wistar rats. Asian Pacific Journal of Tropical Disease 2(4):307-311. https://doi.org/10.1016/s2222-1808(12)60067-X

Toth S, Stricik M, Tyr S, VeresT (2012). The possibilities of Slovakian pyrethrum production. Journal Pesticides and Phytomedicine 27(3):245-252. https://doi.org/10.2298/pif1203245t

Tyagi S, Mohd, Mansoori H, Singh NK, Shivhare MK, Bhardwaj P, Singh RK (2011). Antidiabetic effect of Anacyclus pyrethrum DC in alloxan induced diabetic rats. European Journal of Biological Science 3(4):117-120.

Usmani A, Khushtar M, Arif M, Siddiqui MA, Sing SP, Mujahid M (2016). Pharmacognostic and phytopharmacology study of Anacyclus pyrethrum: An insight. Journal of Applied Pharmaceutical Science 6:144-150. https://doi.org/10.7324/japs.2016.60325

Vaghefi N, Hay FS, Pethybridge SJ, Ford R, Taylor PWJ (2016). Development of a multiplex PCR diagnostic assay for the detection of Stagonosporpsis species associated with ray blight of Asteraceae. European Journal of Plant Pathology 146:581-595. https://doi.org/10.1007/s10658-016-0944-4

Veryser L, Taevernier L, Roche N, Peremans K, Butvenich C, De Spiegeleer B (2014). Quantitative transdermal behaviour of pellitorine from Anacyclus pyrethrumextract. Phytomedicine 21(14):1801-1807. https://doi.org/10.1016/j.phymed.2014.08.015

Wandahwa P, van Ranst E (1996). Qualitative land suitability assessment for pyrethrum cultivation in west Kenya based upon computer-captured expert knowledge and GIS. Agriculture, Ecosystem and Environment 56:187-202. https://doi.org/10.1016/0167-8809(95)00641-9

Zaidi SMA, Pathan SA, Jain GK, Ahmad FJ, Jamil S, Singh S, Khar RK (2009). Anticonvulsant and neuropharmacological studies of Anacycluspyrethrum root extract. Neuroscience Research 65(1):S250. https://doi.org/10.1016/j.neures.2009.09.1423 
OPEN ACCESS The journal offers free, immediate, and unrestricted access to peer-reviewed research and scholarly work. Users are allowed to read, download, copy, distribute, print, search, or link to the full texts of the articles, or use them for any other lawful purpose, without asking prior permission from the publisher or the author.

(C) (9)

License - Articles published in Notulae Scientia Biologicae are Open-Access, distributed under the terms and conditions of the Creative Commons Attribution (CC BY 4.0) License.

(c) Articles by the authors; SHST, Cluj-Napoca, Romania. The journal allows the author(s) to hold the copyright/to retain publishing rights without restriction. 